\title{
Maistui skirto sirupo su biologiškai aktyviomis medžiagomis gamybos, panaudojant natūralią medaus invertazę, tyrimai
}

Ervydas Juodišius ${ }^{1}$,

Aušra Šimonèlienè ${ }^{2}$

${ }^{1}$ Kauno technologijos universitetas, Maisto institutas, Taikos pr. 92, LT-51180 Kaunas

El.paštas:ervydas.juodisius@ktu.lt

${ }^{2}$ Kauno kolegija, Pramonès pr. 20, LT-50468 Kaunas

El.paštas: ausra.simoneliene@kauko.lt
Darbo tikslas - ištirti maistui skirtų produktų, savo sudètimi artimų augaliniam medui, gamybos galimybes, panaudojant natūraliame meduje esančią invertazę cukrui invertuoti ir džiovintų vaistinių augalų vandeninius ekstraktus, bei ištirti pagamintų produktų fizikines-chemines savybes.

Buvo tiriama vaistinių augalų: vaistinių ramunèlių (Matricaria recutica L.), liepos žiedų (Tilia cordata), melisų (Melissa officinalis L.) bei pipirméčių (Mentha piperita L.) vandeninių ekstraktų įtaka sacharozės fermentinès katalizės, naudojant natūralaus žiedų medaus invertazę, reakcijos greičiui. Nustatyta, kad vaistinių augalų ekstraktai lètina sacharozès inversijos procesą. Iš visų tirtų vaistinių augalų ekstraktų labiausiai sulètina fermentinę katalizę melisų (Melissa officinalis L.) ir mètų (Mentha piperita L.) vandeniniai ekstraktai. Sacharozès skilimo pusperiodis bandiniuose su melisų vandeniniu ekstraktu buvo 14,5 val. ilgesnis nei kontrolinio bandinio, o bandinio su mètų ekstraktu skilimo pusperiodis ilgesnis už kontrolinio bandinio tą patị rodiklį beveik $11 \mathrm{val}$.

Pagaminti produktai, panaudojant natūralaus žiedų medaus invertazę, savo fizikiniais-cheminiais rodikliais buvo artimi natūralaus medaus analogiškiems rodikliams. Šie produktai nerūgsta laikomi $35^{\circ} \mathrm{C}$ temperatūroje, nors jų drègnis truputị didesnis nei $20 \%$.

Raktažodžiai: vaistinių augalų ekstraktas, medus, sirupas, inversija

\section{IVADAS}

Jau keletą dešimtmečių bitininkai kai kuriose šalyse, pavyzdžiui, Rusijoje (Йориш, 1976), Lenkijoje (Czaplicki, 2003) rekomenduoja po didžiojo medunešio, išsukus medų, bites maitinti vaisių, vaistinių augalų sultimis arba vaistinių augalų nuovirais, sumaišytais su cukraus sirupu. Bitėms, sunešus ị korius tokị sirupą ir jị užakiavus, išsuktas produktas turi biologiškai aktyvių, iš vaistažolių perèjusių, medžiagų. Tokių biologiškai aktyvių medžiagų nebūna net žiedų meduje. Taigi, yra galimybè, panaudojus bičių biotechnologiją, gauti produktus su iš anksto numatytomis profilaktinemis ir net gydomosiomis savybėmis. Toks „medus“ gali būti naudojamas kaip sveikatinantis, profilaktinis maisto papildas arba kaip sudètine gydomųjų sirupų bei kosmetikos priemonių dalis.

Šis „medus“" gali būti gaminamas tik pasibaigus didžiajam medunešiui ir išsukus per vasarą suneštą žiedų medų ir lipčių. Likęs laiko tarpas (apie 20 dienų) iki bičių paruošimo žiemai labai trumpas ir riboja tokių produktų gamybos apimtis. Be to, reiketų dar nuodugniau ištirti, kaip toks intensyvus bičiu išnaudojimas veikia bičiu šeimos žiemojimą ir vystymąsi pavasari, nors literatūroje yra nuorodų teigiančių, kad dilgèlių sirupas bitèms yra naudingas (Pohorecka, 2004).
Visų minètų žinomų ir dar nežinomų neigiamų veiksnių galima būtų išvengti gaminant analogiškus medui produktus, panaudojant pačiame meduje esančią natūralią invertazę. Invertuoto cukraus sirupo ruošimas bičių maitinimui prieš žiemą, naudojant mielių arba natūralią invertazę, yra žinomas ir jau naudojamas (Ceksterytè, 2006). Panašiu būdu galima būtų gaminti ir produktus žmonių mitybai su vaistinių augalų ekstraktais. Tačiau žinoma, kad fermentinès katalizès aktyvumas susijęs su fermentų baltyminès struktūros ypatybèmis. Fermentų globulinų sandara, palaikoma santykinai silpnomis cheminemis jungtimis tarp atskirų polipeptidinès grandinès dalių, lengvai pažeidžiama pakitus terpès rūgštingumui, temperatūrai, druskų koncentracijai ir pan. Kadangi fermentinei katalizei būtina tiksli fermento struktūra, visi šie faktoriai įtakoja jo aktyvumą. Kiekvienas fermentas maksimaliai aktyvus tik esant atitinkamai temperatūrai, terpès $\mathrm{pH}$ ir kitiems faktoriams, $o$ iš vaistinių augalų ekstrahuojasi daugybė ịvairios cheminès sudèties junginių, ir, pasikeitus terpès sąlygoms i bet kurią pusę nuo optimalių, sumažèja fermentinès katalizès aktyvumas (Дженке, 1972).

Darbo tikslas - ištirti maistui skirtų produktų, savo sudètimi artimų augaliniam medui, gamybos galimybes, 
panaudojant natūraliame meduje esančią invertazę cukrui invertuoti ir džiovintų vaistinių augalų vandeninius ekstraktus bei ištirti pagamintų produktų fizikines-chemines savybes.

\section{TYRIMŲ SĄLYGOS IR METODAI}

\section{Vaistinių augalų žaliavos ruošimas}

Vaistinès ramunèlès - Matricaria recutica $\mathrm{L}$.

Vaistinès ramunèlès žiedai (Matricariae flos) buvo pirkti vaistinejje. Gamintojas - UAB „Acorus calamus“.

Vaistinių ramunių žieduose yra iki $8 \%$ flavonoidų, tarp jų - apigenino ir luteolino, 0,4-2 \% eterinių aliejų, kuriuos sudaro bisabololis (iki $5 \%$ ), chamazulenas 1-15\%) ir seskviterpeniniai laktonai (matricinas ir matrikarinas), polisacharidų (gleivių), aminorugščių, riebalų rugščių, fenolinių rugščių, cholino (iki 3 \%) ir kumarinų (iki 0,1 \%) (Kranzberger, 2000).

Liaudies medicina vaistinès ramunèlès arbatas pataria vartoti dujų žarnyne mažinimui, esant peršalimui ir kaip raminančią priemonę prieš miegą.

Mažalapė liepa - Tilia cordata Mill. Liepų žieduose randama eterinio aliejaus (farnezolio, geraniolio, eugenolio), iki $10 \%$ polisacharidų, iki $4 \%$ flavanoidų (rutino, kvercitrino), fenolkarboninių rūgščių, chlorogeno ir kavos rūgščių, taip pat amino rūgščių (alanino, cisteino, cistino ir fenilalanino), vitamino C (Barnes, 2002).

Liepų žiedai (Tiliae flos) buvo pirkti vaistineje. Gamintojas - UAB „Acorus calamus“. Žiedai smulkinti.

Šių žiedų nuoviras buvo gleivingas ir jame buvo daug smukių dulkių pavidalo dalelių. Medžiaginiai filtrai neatskyrè pakibusių dalelių, o popierinis filtras užsikimšdavo ir nebuvo galima nuoviro nufiltruoti. Todèl buvo panaudoti birželio pabaigoje surinkti liepų žiedynai, o smulkintų liepžiedžių nuoviras buvo ruošiamas juos patalpinus i filtro popieriaus maišelį.

Žaliavą sudare išsiskleidę žiedai, neišsivystę žiedai - butonai ir nesunokę vaisiai - riešutèliai. Visa tai buvo išdžiovinta vėdinamoje patalpoje, ne aukštesnèje kaip $35{ }^{\circ} \mathrm{C}$ temperatūroje. Išdžiūvusių žiedų kvapas silpnas, malonus, skonis saldokas, silpnai sutraukiantis.

Liepos žiedų preparatai pasižymi raminančiu, šlapimą varančiu, prakaitavimą skatinančiu, karščiavimą mažinančiu, atsikosėjimą gerinančiu, antibakteriniu ir priešuždegiminiu poveikiu.

Vaistinè melisa - Melissa officinalis L. Melisų lapų eteriniame aliejuje, kurio lapuose yra 0,02-0,35 \%, esantiems citraliui ir linaloliui, geranioliui, geranilacetatui, beta kariofilenui, kariofileno epoksidui būdingas spazmolizinis poveikis, veikiantis bakterijas ir grybelius. Antimikrobinis poveikis būdingas ir aliejuje esantiems fenolkarboksirūgščių junginiams - rozmarinų rūgščiai, kurios būna iki 4,7 \%. Lapuose flavonoidų yra iki 0,003 \%, tai ramnocitrinas, izokvercitrinas. Taip pat melisų lapuose yra raugų, askorbo rūgšties, karotino, seleno (Kranzberger, 2002).
Melisos žolè (Melissae herba) buvo užauginta sode. Antžeminė augalo dalis - 15-30 cm ilgio stiebų viršūnès su lapais ir stiebais - nupjauta prieš pat žydejjimą. Išdžiovinta gerai védinamoje patalpoje, ne aukštesnèje $40{ }^{\circ} \mathrm{C}$ temperatūroje. Išdžiovinta žaliava žalios spalvos, kartoko, bet malonaus skonio, citrinų kvapo.

Melisos užpilai ir nuovirai, sirupai naudojami virškinimą gerinančių, raminančių vaistažolių mišiniuose. Melisos ekstraktai būna raminančių vaistų formų sudètyje.

Melisa pasižymi raminančiu, skausmą mažinančiu, silpnu antibakteriniu, kraujagysles plečiančiu ir kraujospūdi mažinančiu poveikiu. Gerina apetitą, virškinamojo trakto veiklą, atpalaiduoja žarnyno spazmus, skatina tulžies išsiskyrimą, slopina pykinimą ir vėmimą.

Pipirmètė - Mentha piperita L. Pipirmètès žolè buvo užauginta sode. Pipirméčių lapai (Menthae piperitae folium) buvo ruošiami pjaunant pradejjusią žydèti visą žolę (stiebus su lapais ir žiedynais). Išrinkus priemaišas ji buvo džiovinama, plonai paskleidus palèpeje, ne aukštesnèje nei $35{ }^{\circ} \mathrm{C}$ temperatūroje. Išdžiūvus žaliavai, lapai buvo nubraukti rankomis. Išdžiovinti lapai malonaus kvapo, sutraukiančio šaldančio skonio.

Pipirmečiu lapuose yra 1,2-3 \% eterinių aliejų, kurių didžiąją dali sudaro monoterpenai: mentolis (29-55 \%), mentonas (10-40\%), cineolas (2-13\%), pulegonas (1-11\%), mentilacetatas (1-10\%), mentofuranas (0-10\%), limonenas $(0,2-6 \%)$. Taip pat yra flavonoidų (luteolino, hesperidino, rutino), kavos, chlorogeno ir rozmarino rūgščių bei giminiškų taninų, cholino, $\alpha$ - ir $\beta$-karotenų, sakų, mineralinių medžiagų, dervų, $\alpha$ - bei $\gamma$-tokoferolių, triterpenų $a$-amirino ir skvaleno (Kranzberger, 2000).

Pipirmètès užpilai naudojami vidurių lašų, virškinimą gerinančių mišinių gamyboje.

Pipirmètès preparatai gerina apetitą, virškinimą, skatindami virškinimo liaukų sekreciją, veikia spazmolitiškai, priešuždegimiškai, skausmą slopinančiai, skatina tulžies išsiskyrimą.

\section{Bandinių ruošimas}

Iš vaistinių augalų buvo paruoštos vandeninès ištraukos. 6 g kiekvienos vaistinès žaliavos buvo užpilta $200 \mathrm{ml}$ verdančio distiliuoto vandens ir palaikyta $15 \mathrm{~min}$. Kiekvienos vandeninès ištraukos $100 \mathrm{ml}$ buvo ištirpinta po $200 \mathrm{~g}$ baltojo cukraus.

I kiekvieną tirpalą pridèjus po $100 \mathrm{~g}$ natūralaus žiedų medaus, buvo pradèta skaičiuoti fermentinès katalizès reakcijos pradžia.

Kontrolei buvo naudojamas tokiu pačiu sudedamųjų medžiagų santykiu paruoštas mišinys, tik vietoje vaistingųjų medžiagų ištraukos buvo naudojamas distiliuotas vanduo.

\section{TYRIMO METODAI}

Sacharozès kiekis mišiniuose buvo matuojamas Rudolph Research Analytical firmos automatiniu poliarimetru 
„Autopol I“. Užpildžius mėginiu vamzdelį, jis buvo palaikomas keletą minučių, kad temperatūra nuo $35^{\circ} \mathrm{C}$, prie kurios buvo termostatuojami pavyzdžiai, nukristų iki artimos $20^{\circ} \mathrm{C}$ temperatūros. Matavimo metu prietaisas automatiškai atlieka rezultatų temperatūrinę korekciją pagal formulę:

$$
a_{20}=\alpha_{T}\left[1+0,000155\left(T_{s}-20\right)\right],
$$

$a_{20}$ - optinè kvarco méginio rotacija ( $\left.{ }^{\circ} \mathrm{Arc}\right)$ koreguota $20{ }^{\circ} \mathrm{C}$;

$a_{T}$ - sacharozès méginio nekoreguota optiné rotacija ( $\left.{ }^{\circ} \mathrm{Arc}\right)$;

$T_{s}$ - sacharozès méginio temperatūra.

Poliarimetrui buvo užduotas darbas sacharimetro, kurio skalè sugraduota pagal ICUMSA $1988 \mathrm{~m}$. standartą ${ }^{\circ} \mathrm{Z}$ laipsniais, režimu. Matavimai atlikti esant 589,3 nm šviesos bangos ilgiui.

\section{TYRIMŲ REZULTATAI IR JŲ APTARIMAS}

Vaistinių augalų vandeninių ekstraktų įtaka sacharozès fermentinès katalizès reakcijai

Kadangi terpès $\mathrm{pH}$ ịtakoja fermentinès katalizès greiti, buvo nustatytas bandymuose panaudotų augalų vandeninių ekstraktų aktyvusis rūgštingumas, kurių duomenys pateikti 1 lentelèje.

Visi ekstraktai švelniai rūgštiniai. Tik galima atkreipti dėmesị ị smulkintų ir nesmulkintų liepžiedžių nuovirų $\mathrm{pH}$ skirtumą. Gleivès, išsiskiriančios iš smulkintų liepų žiedų,

1 lentelè. Vaistingujų augalų vandeninių ekstraktų aktyvusis rūgštingumas $\mathrm{pH}$

Table 1. Active acidity (pH) of the medicinal plant aqueous extracts

\begin{tabular}{c|c|c|c|c}
\hline $\begin{array}{c}\text { Mètos } \\
\text { Mint }\end{array}$ & $\begin{array}{c}\text { Vaistinès } \\
\text { ramunèlès } \\
\text { Medicinal } \\
\text { chamomile }\end{array}$ & $\begin{array}{c}\text { Smulkinti } \\
\text { liepų žiedai } \\
\text { Grated lime } \\
\text { flowers }\end{array}$ & $\begin{array}{c}\text { Nesmul- } \\
\text { kinti liepu } \\
\text { žiedai } \\
\text { Whole lime } \\
\text { flowers }\end{array}$ & $\begin{array}{c}\text { Melisos } \\
\text { Melissa }\end{array}$ \\
\hline $5,85 \pm 0,03$ & $5,92 \pm 0,02$ & $5,69 \pm 0,03$ & $5,57 \pm 0,03$ & $6,00 \pm 0,02$ \\
\hline
\end{tabular}

mažina nuoviro rūgštingumą. Bandymams naudoto medaus aktyvusis rūgštingumas buvo 4,28.

Kadangi cukrus, tirpdamas vandenyje, nekeičia aktyviojo rūgštingumo, tai kontrolinio ir bandymams skirtų bandinių su ištirpintu cukrumi pH nebuvo matuojamas. Buvo išmatuoti tik ${ }^{\circ} \mathrm{Z}$, duomenys pateikiami 2 lentelèje.

Tirpalo, kuriame yra optiškai aktyvių medžagų, poliarizuotos šviesos sukimo kampas lygus algebrinei kiekvienos jame esančios optiškai aktyvios medžiagos sukimo kampu sumai. Esant $20^{\circ} \mathrm{C}$ ir bangos ilgiui $\lambda=589,3 \mathrm{~nm}$, vandeniniu sacharozès tirpalų sukimo kampas $[\alpha]_{D}{ }^{20}=66,5^{\circ}$; gliukozès $[\alpha]_{D}{ }^{20}=52,7^{\circ}$; fruktozès $[\alpha]_{D}{ }^{20}=-92^{\circ}$. Sacharozè ir gliukozè poliarizuotą šviesą suka i dešinę, o fruktozė labai stipriai i kairę (Манапова, 2006). Kadangi su vaistingujų augalų vandeninėmis ištraukomis paruoštų tirpalų ${ }^{\circ} \mathrm{Z}$ rodikliai skyrèsi nuo 47,81 (melisa) iki -6,418 (vaistinès ramunèlès), buvo išmatuotas optinis vaistingųjų augalų vandeninių ekstraktų optinis aktyvumas (3 lentelè).

Kaip matyti iš 3 lentelëje pateiktų duomenų, visi ekstraktai optiškai aktyvūs, išskyrus liepžiedžių ekstraktus, ir visi jie suka poliarizuotą šviesą i kairę. Galima manyti, kad tai ekstraktuose esančios fruktozès, o gal kitų optiškai aktyvių medžiagų rezultatas. Tačiau gautos skaitinès reikšmès nepaaiškina 2 lentelèje esančių duomenų skaitinių reikšmių skirtumų.

Sumaišius paruoštus tirpalus su medumi, prasideda sacharozès fermentinès katalizès reakcija, tačiau dèl didelio mišinio klampio, maišymo metu patekę oro burbuliukai ilgai neiškyla i paviršių ir apie 20 min. negalima atlikti optinių matavimų.

Kontrolinio pavyzdžio tyrimo duomenys pateikti 4 lentelèje.

Vykstant sacharozès hidrolizei susidaro D-gliukozė ir Dfruktozè.

$$
\begin{aligned}
& \mathrm{H}^{+} \\
& \underset{12}{\mathrm{C}_{12} \mathrm{H}_{22} \mathrm{O}_{11}}+\mathrm{H}_{2} \mathrm{O} \rightarrow \underset{6}{\mathrm{C} \text {-gliukoze }} \mathrm{C}_{12} \mathrm{O}_{6}+\mathrm{C}_{6} \mathrm{H}_{12} \mathrm{O}_{6} \\
& \text { D-fruktoze }
\end{aligned}
$$

Naudojantis šia integruota formule (Malinauskas, 2005)

$$
k_{\mathrm{I}}=1 / t \times \ln a / a-x,
$$

2 lentelè. Bandinių optinis aktyvumas, prieš sumaišant su medumi ${ }^{\circ} Z$

Table 2. Optical activity ( $\left.{ }^{\circ} \mathrm{Z}\right)$ of the samples before mixing with honey

\begin{tabular}{c|c|c|c|c|c}
\hline $\begin{array}{c}\text { Mètos } \\
\text { Mint }\end{array}$ & $\begin{array}{c}\text { Vaistinés ramunèlés } \\
\text { Medicinal chamomile }\end{array}$ & $\begin{array}{c}\text { Smulkinti liepų žiedai } \\
\text { Grated lime flowers }\end{array}$ & $\begin{array}{c}\text { Nesmulkinti liepų žiedai } \\
\text { Whole lime flowers }\end{array}$ & $\begin{array}{c}\text { Melisos } \\
\text { Melissa }\end{array}$ & $\begin{array}{c}\text { Kontrolinis bandinys } \\
\text { Control }\end{array}$ \\
\hline $168,65 \pm 0,104$ & $170,298 \pm 0,009$ & $167,408 \pm 0,016$ & $167,408 \pm 0,016$ & $116,070 \pm 0,027$ & $163,880 \pm 0,031$ \\
\hline
\end{tabular}

3 lentelè. Vaistingujų augalų vandeninių ekstraktų optinis aktyvumas ${ }^{\circ} \mathbf{Z}$

Table 3. Optical activity $\left({ }^{\circ} \mathrm{Z}\right)$ of the medicinal plant aqueous extracts

\begin{tabular}{c|c|c|c|c}
\hline $\begin{array}{c}\text { Mètų ekstraktas } \\
\text { Extract of mint }\end{array}$ & $\begin{array}{c}\text { Vaistinių ramunèlių ekstraktas } \\
\text { Extract of medicinal chamomile }\end{array}$ & $\begin{array}{c}\text { Smulkintų liepų žiedų ekstraktas } \\
\text { Extract of grated lime flowers }\end{array}$ & $\begin{array}{c}\text { Nesmulkintų liepų žiedų ekstraktas } \\
\text { Extract of whole lime flowers }\end{array}$ & $\begin{array}{c}\text { Melisos ekstraktas } \\
\text { Extract of melissa }\end{array}$ \\
\hline$-0,20 \pm 0,014$ & $-0,17 \pm 0,008$ & $0,00 \pm 0,000$ & $0,00 \pm 0,000$ & $-0,06 \pm 0,007$ \\
\hline
\end{tabular}


4 lentelè. Kontrolinio pavyzdžio sacharozės fermentinès katalizės priklausomybė nuo reakcijos laiko

Table 4. Dependency of the sucrose enzyme catalysis on reaction time in the control sample

\begin{tabular}{c|c|c|c}
\hline $\begin{array}{c}\text { Reakcijos laikas min. } \\
\text { Reaction time, } \text { min. }\end{array}$ & $\begin{array}{c}\text { Sacharozés kiekis mišnyje }{ }^{\circ} \mathbf{Z} \\
\text { Sucrose content, }{ }^{\circ} \mathbf{Z}\end{array}$ & $\begin{array}{c}\text { Didžiausia reikšme }{ }^{\circ} \mathbf{Z} \\
\text { Max, }{ }^{\circ} \mathbf{Z}\end{array}$ & $\begin{array}{c}\text { Mažiausia reikšme }{ }^{\circ} \mathbf{Z} \\
\text { Min, }{ }^{\circ} \mathbf{Z}\end{array}$ \\
\hline 27 & $116,655 \pm 0,009$ & 116,67 & 116,65 \\
\hline 67 & $114,946 \pm 0,013$ & 114,97 & 114,94 \\
\hline 125 & $112,322 \pm 0,016$ & 112,34 & 109,19 \\
\hline 145 & $109,250 \pm 0,037$ & 109,28 & 107,26 \\
\hline 253 & $107,260 \pm 0,000$ & 107,26 & 102,73 \\
\hline 371 & $102,730 \pm 0,000$ & 102,73 & 97,93 \\
\hline 497 & $97,948 \pm 0,016$ & 97,96 & \\
\hline 1257 & $73,102 \pm 0,016$ & 73,12 \\
\end{tabular}

$k_{\mathrm{I}}$ - pirmojo laipsnio reakcijos greičio konstanta,

$t$ - reakcijos laikas,

$a$ - sacharozès koncentracija pradiniu reakcijos momentu,

$x$ - sureagavusios sacharozės kiekis, galima patikrinti, ar nagrinejjama reakcija priklauso pirmojo laipsnio reakcijoms. Kadangi negalejome atlikti matavimų reakcijos pradžioje, norèdami nustatyti sacharozès koncentraciją pradiniu reakcijos momentu, tai ši rodikli nustatėme ekstrapoliacijos būdu. Kadangi kontrolinio pavyzdžio ${ }^{\circ} \mathrm{Z}$ ir reakcijos laiko funkcinè priklausomybè aprašoma regresijos lygtimi

$$
\begin{aligned}
& y=117,52 \mathrm{e}^{-0,0004 x} \\
& y \text { - sacharozès koncentracija }{ }^{\circ} \mathrm{Z} ; \\
& x \text { - reakcijos laikas min., }
\end{aligned}
$$

tai $x=0, y=117,52^{\circ} \mathrm{Z}$ - sacharozès koncentracija reakcijos pradžioje.

Apskaičiavus eksperimentinius duomenis pagal lygtị 2 (apskaičiuotos $k$ reikšmès), duomenys pateikiami 5 lentelèje.

5 lentelè. Kontrolinio pavyzdžio sacharozès fermentinès katalizės laiko ir reakcijos greičio konstantos

Table 5. Time and rate constants of the sucrose enzyme-catalysed reaction in the control sample

\begin{tabular}{c|c}
\hline $\mathbf{t}$ min. & $\mathbf{k ~ m i n}^{-1}$ \\
\hline 27 & 0,000274 \\
\hline 67 & 0,000331 \\
\hline 125 & 0,000362 \\
\hline 253 & 0,000361 \\
\hline 371 & 0,000363 \\
\hline 497 & 0,000367 \\
\hline 1257 & 0,000378
\end{tabular}

Kadangi atskirais laiko tarpais $\mathrm{k}$ reikšmès praktiškai vienodos, tai ši reakcija turi būti priskiriama pirmojo laipsnio, tiksliau pseudo pirmojo laipsnio reakcijoms.

Visoms pirmojo laipsnio reakcijoms galioja šie dèsningumai:
1. Pirmojo laipsnio reakcijos greičio konstantos dimensija yra atvirkštinis laikas, ją galima išreikšti $\mathrm{s}^{-1}, \mathrm{~min}^{-1}, \mathrm{~h}^{-1}$ ir pan.

2. Kadangi koncentracijos ieina ì lygtis kaip santykiai, nèra svarbu, kokiais vienetais jos matuojamos, nuo to $k$ reikšmès nepriklauso.

3. Pirmojo laipsnio reakcijoms vienodoms laiko atkarpoms atitinka vienodas sureagavusios medžiagos kiekis.

Išanalizavus bandinio su vaistinių ramunèlių ekstraktu fermentinès katalizès priklausomybę nuo reakcijos laiko, duomenys pateikiami 6 lentelëje.

6 lentelè. Bandinio su vaistinių ramunèliu ekstraktu fermentinès katalizės priklausomybè nuo reakcijos laiko

Table 6. Dependency of enzyme catalysis on the reaction time in the sample of medicinal chamomile extract

\begin{tabular}{c|c|c|c}
\hline $\begin{array}{c}\text { Reakcijos laikas } \\
\text { min. } \\
\text { Reaction time, } \text { min. }\end{array}$ & $\begin{array}{c}\text { Sacharozès kiekis } \\
{\text { mišnyje }{ }^{\circ} \mathbf{Z}}^{\text {Sucrosecontent, }{ }^{\circ} \mathbf{Z}}\end{array}$ & $\begin{array}{c}\text { Didžiausia } \\
\text { reikšme }^{\circ} \mathbf{Z} \\
\text { Max, }^{\circ} \mathbf{Z}\end{array}$ & $\begin{array}{c}\text { Mažiausia } \\
\text { reikšme }^{\circ} \mathbf{Z} \\
\text { Min, }^{\circ} \mathbf{Z}\end{array}$ \\
\hline 27 & $114,080 \pm 0$ & 114,08 & 114,08 \\
\hline 63 & $113,264 \pm 0,013$ & 113,27 & 113,24 \\
\hline 1010 & $84,458 \pm 0,016$ & 84,47 & 84,44 \\
\hline 1020 & $82,540 \pm 0,000$ & 82,54 & 82,54 \\
\hline 1112 & $81,646 \pm 0,039$ & 81,70 & 81,61 \\
\hline 1117 & $80,648 \pm 0,016$ & 80,66 & 80,63 \\
\hline 1227 & $79,396 \pm 0,025$ & 79,42 & 79,36 \\
\hline 1319 & $77,528 \pm 0,016$ & 77,54 & 77,51 \\
\hline 1453 & $75,834 \pm 0,016$ & 74,86 & 74,83 \\
\hline 2447 & $60,772 \pm 0,034$ & 60,82 & 60,73 \\
\hline
\end{tabular}

Bandinio su vaistinių ramunèlių ekstraktu ${ }^{\circ} \mathrm{Z}$ ir reakcijos laiko funkcinė priklausomybė aprašoma lygtimi

$$
y=111,74 \mathrm{e}^{-0,0003 x}
$$

Kaip matome, pirmosios dvi apskaičiuotos konstantos turi neigiamas reikšmes, nes ekstrapoliacijos būdu pagal 4 lygti nustatyta pradinè sacharozès koncentracija $111,74^{\circ} \mathrm{Z}$ yra mažesnè nei koncentracijos išmatuotos 27 ir 63 reakcijos minutèmis (7 lentelè). Tai gali būti matavimų netikslumai, nes visos kitos reakcijos greičio konstantos praktiškai gana artimos. 
7 lentelè. Bandinio su vaistinių ramunèlių ekstraktu sacharozès fermentinès katalizés laiko ir reakcijos greičio konstantos

Table 7. Time and rate constants of the sucrose enzyme-catalysed reaction in the sample of medicinal chamomile extract

\begin{tabular}{c|c}
\hline $\mathbf{t}$ min. & $\mathbf{k ~ m}^{\mathbf{1}}$ \\
\hline 27 & $-0,00077$ \\
\hline 63 & $-0,00022$ \\
\hline 1010 & 0,000277 \\
\hline 1020 & 0,000297 \\
\hline 1112 & 0,000282 \\
\hline 1117 & 0,000292 \\
\hline 1227 & 0,000279 \\
\hline 1319 & 0,000277 \\
\hline 1453 & 0,000267 \\
\hline 2447 & 0,000249
\end{tabular}

Bandinio su melisų ekstraktu fermentinès katalizès priklausomybè nuo reakcijos laiko pateikiama 8 lenteleje.

Bandinio su melisų ekstraktu ${ }^{\circ} \mathrm{Z}$ ir reakcijos laiko funkcinè priklausomybė aprašoma lygtimi

$$
y=116,16 \mathrm{e}^{-0,0002 x}
$$

Apskaičiuotos bandinio su melisų ekstraktu sacharozės fermentinès katalizès laiko ir reakcijos greičio konstantos (9 lentelè).
9 lentelè. Bandinio su melisų ekstraktu sacharozés fermentinès katalizès laiko ir reakcijos greičio konstantos

Table 9. Time and rate constants of the sucrose enzyme-catalysed reaction in the sample of Melissa extract

\begin{tabular}{c|c}
\hline $\mathbf{t}$ min. & $\mathbf{k ~ m}^{\mathbf{1}}$ \\
\hline 82 & 0,000000945 \\
\hline 117 & 0,00000714 \\
\hline 1105 & 0,000250 \\
\hline 1265 & 0,000257 \\
\hline 1397 & 0,000250 \\
\hline 1557 & 0,000235 \\
\hline 2512 & 0,000219 \\
\hline
\end{tabular}

Kaip ir bandinių su vaistinių ramunèlių ekstraktu tyrimuose, taip ir su melisų ekstraktu, pirmosios dvi apskaičiuotos konstantos savo reikšmėmis išsiskiria iš kitų, tačiau pastarosios kinta labai mažai.

Nustatyta bandinio su mètų ekstraktu fermentinès katalizès priklausomybè nuo reakcijos laiko (10 lentelè).

Bandinio su mètų ekstraktu ${ }^{\circ} \mathrm{Z}$ ir reakcijos laiko funkcinè priklausomybe aprašoma lygtimi

$$
y=116,19^{\mathrm{e}-0,0003 \mathrm{x}} .
$$

Apskaičiuotos bandinio su mètų ekstraktu sacharozès fermentinès katalizės laiko ir reakcijos greičio konstantos (11 lentelè).

8 lentelè. Bandinio su melisų ekstraktu fermentinès katalizės priklausomybẻ nuo reakcijos laiko

Table 8. Dependency of enzyme catalysis on reaction time in the sample of Melissa extract

\begin{tabular}{c|c|c|c}
\hline $\begin{array}{c}\text { Reakcijos laikas min. } \\
\text { Reaction time, } \text { min. }\end{array}$ & $\begin{array}{c}\text { Sacharozes kiekis mišnyje }{ }^{\circ} \mathbf{Z} \\
\text { Sucrosecontent, }{ }^{\circ} \mathbf{Z}\end{array}$ & $\begin{array}{c}\text { Didžiausia reikšme }{ }^{\circ} \mathbf{Z} \\
\text { Max, }^{\circ} \mathbf{Z}\end{array}$ & $\begin{array}{c}\text { Mažiausia reikšme }{ }^{\circ} \mathbf{Z} \\
\text { Min, }{ }^{\circ} \mathbf{Z}\end{array}$ \\
\hline 82 & $116,07 \pm 0,027$ & 116,10 & 116,04 \\
\hline 117 & $115,194 \pm 0,013$ & 115,20 & 88,17 \\
\hline 1105 & $88,092 \pm 0,016$ & 88,20 & 83,92 \\
\hline 1265 & $83,920 \pm 0,000$ & 83,92 & 81,93 \\
\hline 1397 & $81,960 \pm 0,021$ & 81,99 & 80,52 \\
\hline 1557 & $80,552 \pm 0,20$ & 80,57 & 66,91 \\
\hline
\end{tabular}

10 lentelè. Bandinio su mètų ekstraktu fermentinès katalizės priklausomybè nuo reakcijos laiko

\begin{tabular}{|c|c|c|c|}
\hline $\begin{array}{l}\text { Reakcijos laikas min. } \\
\text { Reaction time, } \min .\end{array}$ & $\begin{array}{l}\text { Sacharozès kiekis mišnyje }{ }^{\circ} \mathrm{Z} \\
\text { Sucrosecontent, }{ }^{\circ} \mathrm{Z}\end{array}$ & $\begin{array}{c}\text { Didžiausia reikšmé }{ }^{\circ} Z \\
\text { Max, }{ }^{\circ} Z\end{array}$ & $\begin{array}{c}\text { Mažiausia reikšme }{ }^{\circ} Z \\
\text { Min, }{ }^{\circ} Z\end{array}$ \\
\hline 63 & $120,138 \pm 0,094$ & 120,40 & 120,17 \\
\hline 93 & $117,842 \pm 0,086$ & 117,95 & 117,74 \\
\hline 1018 & $87,740 \pm 0,021$ & 87,77 & 87,71 \\
\hline 1085 & $84,948 \pm 0,011$ & 84,96 & 84,94 \\
\hline 1279 & $82,612 \pm 0,016$ & 82,63 & 82,60 \\
\hline 1375 & $81,058 \pm 0,016$ & 81,07 & 81,04 \\
\hline 1500 & $78,720 \pm 0,182$ & 78,96 & 78,55 \\
\hline 2481 & $64,642 \pm 0,016$ & 64,66 & 64,63 \\
\hline
\end{tabular}

Table 10. Dependency of enzyme-catalysed reaction on the time period in the sample of mint extract 
11 lentelè. Bandinio su mètų ekstraktu sacharozės fermentinės katalizès laiko ir reakcijos greičio konstantos

Table 11. Time and rate constants of the succrose enzyme-catalysed reaction in the sample of mint extract

\begin{tabular}{cc}
\hline $\mathbf{t}$ min. & $\mathbf{k ~ m i n}^{-1}$ \\
\hline 63 & $-0,00011$ \\
\hline 93 & 0,00000176 \\
\hline 1018 & 0,000276 \\
\hline 1085 & 0,000269 \\
\hline 1279 & 0,000267 \\
\hline 1375 & 0,000262 \\
\hline 1500 & 0,00026 \\
\hline 2481 & 0,000236 \\
\hline
\end{tabular}

Kaip ir ankstesnių nagrinètų bandymų rezultatuose, bandinių su mètų ekstraktu tyrimuose taip pat pirmosios dvi apskaičiuotos konstantos savo reikšmėmis išsiskiria iš kitų. Galima manyti, kad sumaišius bandinius su medumi mikroskopiniai oro burbulèliai labai klampioje terpèje neiškyla per tą laiką, kai atliekami pirmieji matavimai, ir daro ịtaką matavimų rezultatams, nors vizualiai tirpalai atrodo pakankamai skaidrūs.

Nustatyta bandinio su nesmulkintų liepų žiedų ekstraktu fermentinès katalizès priklausomybė nuo reakcijos laiko (12 lentelè).

Bandinio su nesmulkintų liepų žiedų ekstraktu ${ }^{\circ} \mathrm{Z}$ ir reakcijos laiko funkcinè priklausomybė aprašoma lygtimi
13 lentelè. Bandinio su nesmulkintų liepų žiedų ekstraktu sacharozės fermentinès katalizés laiko ir reakcijos greičio konstantos

Table 13. Time and rate constants of sucrose enzyme catalysis in the sample of non-crushed lime blossom extract

\begin{tabular}{c|c}
\hline $\mathbf{t}$ min. & $\mathbf{k ~ m i n}^{-1}$ \\
\hline 5 & 0,003608 \\
\hline 137 & 0,000291 \\
\hline 195 & 0,000277 \\
\hline 259 & 0,000296 \\
\hline 308 & 0,000303 \\
\hline 420 & 0,000301 \\
\hline 560 & 0,000302 \\
\hline 1355 & 0,000313 \\
\hline
\end{tabular}

$$
y=118,79^{\mathrm{e}-0,0003 \mathrm{x}}
$$

Apskaičiuotos bandinio su nesmulkintų liepų žiedų ekstraktu sacharozės fermentinès katalizès laiko ir reakcijos greičio konstantos (13 lentelè).

Bandinio su nesmulkintų liepų žiedų ekstraktu katalizès reakcijos greičio koeficientai pakankamai pastovūs, išskyrus pirmojo matavimo (po 5 min. nuo reakcijos pradžios), kuris viena pakopa didesnis už kitus.

Nustatyta bandinio su smulkintų liepų žiedų ekstraktu fermentinès katalizès priklausomybè nuo reakcijos laiko (14 lentelè).

12 lentelè. Bandinio su nesmulkintų liepų žiedų ekstraktu fermentinės katalizės priklausomybè nuo reakcijos laiko

Table 12. Dependency of enzyme catalysis on reaction time in the sample of non-crushed lime blossom extract

\begin{tabular}{c|c|c|c}
\hline $\begin{array}{c}\text { Reakcijos laikas min. } \\
\text { Reaction time, } \text { min. }\end{array}$ & $\begin{array}{c}\text { Sacharozés kiekis mišnyje }{ }^{\circ} \mathbf{Z} \\
\text { Sucrosecontent, }{ }^{\circ} \mathbf{Z}\end{array}$ & $\begin{array}{c}\text { Didžiausia reikšme }{ }^{\circ} \mathbf{Z} \\
\text { Max, }^{\circ} \mathbf{Z}\end{array}$ & $\begin{array}{c}\text { Mažiausia reikšme }{ }^{\circ} \mathbf{Z} \\
\text { Min, }^{\circ} \mathbf{Z}\end{array}$ \\
\hline 5 & $116,666 \pm 0,009$ & 116,67 & 116,65 \\
\hline 137 & $114,148 \pm 0,016$ & 114,16 & 114,13 \\
\hline 195 & $112,538 \pm 0,40$ & 112,60 & 112,49 \\
\hline 259 & $110,012 \pm 0,016$ & 110,03 & 108,21 \\
\hline 308 & $108,210 \pm 0,000$ & 104,75 \\
\hline 420 & $104,666 \pm 0,058$ & 100,30 \\
\hline 560 & $100,282 \pm 0,016$ & 104,60 \\
\hline 1355 & $77,748 \pm 0,022$ & 77,77 \\
\hline
\end{tabular}

14 lentelè. Bandinio su smulkintų liepų žiedų ekstraktu fermentinės katalizės priklausomybė nuo reakcijos laiko

Table 14. Dependency of enzyme catalysis on reaction time in the sample of crushed lime blossom extract

\begin{tabular}{|c|c|c|c|}
\hline $\begin{array}{l}\text { Reakcijos laikas min. } \\
\text { Reaction time, min. }\end{array}$ & $\begin{array}{c}\text { Sacharozès kiekis mišnyje }{ }^{\circ} \mathrm{Z} \\
\text { Sucrosecontent, }{ }^{\circ} \mathrm{Z}\end{array}$ & $\begin{array}{c}\text { Didžiausia reikšmè }{ }^{\circ} \mathrm{Z} \\
\text { Max, }{ }^{\circ} \mathrm{Z}\end{array}$ & $\begin{array}{c}\text { Mažiausia reikšmé }{ }^{\circ} \mathrm{Z} \\
\operatorname{Min},{ }^{\circ} \mathrm{Z}\end{array}$ \\
\hline 47 & $118,634 \pm 0,039$ & 118,67 & 118,58 \\
\hline 142 & $117,038 \pm 0,016$ & 117,05 & 117,02 \\
\hline 210 & $115,054 \pm 0,013$ & 115,06 & 115,03 \\
\hline 280 & $112,866 \pm 0,013$ & 112,89 & 112,86 \\
\hline 327 & $111,058 \pm 0,016$ & 111,07 & 111,04 \\
\hline 435 & $107,786 \pm 0,013$ & 107,81 & 10778 \\
\hline 577 & $103,318 \pm 0,016$ & 103,33 & 103,30 \\
\hline 1369 & $79,910 \pm 0,015$ & 79,91 & 79,88 \\
\hline
\end{tabular}


Bandinio su smulkintų liepų žiedų ekstraktu ${ }^{\circ} \mathrm{Z}$ ir reakcijos laiko koreliacinė priklausomybė išreiškiama regresijos lygtimi

$$
y=122,38 \mathrm{e}^{-0,0003 x} .
$$

Apskaičiuotos bandinio su smulkintų liepų žiedų ekstraktu sacharozès fermentinès katalizès laiko ir reakcijos greičio konstantos (15 lentelè).

Kaip ir visų, išskyrus kontrolinị bandinị, taip ir bandinio su smulkintu liepu žiedu ekstraktu sacharozès fermentinès katalizès reakcijos greičio pirmoji konstanta skiriasi nuo visų kitų. Ji du kartus didesnè nei likusios.

15 lentelè. Bandinio su smulkintų liepų žiedų ekstraktu sacharozès fermentinès katalizés laiko ir reakcijos greičio konstantos

Table 15. Time and rate constants of sucrose enzyme catalysis in the sample of crushed lime blossom extract

\begin{tabular}{cc}
\hline $\mathbf{t}$ $\mathbf{i n}$. & $\mathbf{k ~ m i n}^{\mathbf{1}}$ \\
\hline 47 & 0,000661 \\
\hline 142 & 0,000314 \\
\hline 210 & 0,000294 \\
\hline 280 & 0,000289 \\
\hline 327 & 0,000297 \\
\hline 435 & 0,000292 \\
\hline 577 & 0,000293 \\
\hline 1369 & 0,000311 \\
\hline
\end{tabular}

Pirmojo laipsnio reakcijų greičio ịvertinimui svarbus dydis yra reakcijos pusperiodis, t. y. laikas, per kurị sureaguoja pusė medžiagos, mūsų atveju - sacharozès. Istačius i $x=a / 2$ gaunama lygtis $\tau_{1 / 2}=\ln 2 / k_{\mathrm{I}}=0,693 / k_{\mathrm{I}},(9)$, reakcijos pusperiodžiui apskaičiuoti.

Apskaičiuoti vidutiniai reakcijų greičiai ir sacharozès skilimo pusperiodžiai (16 lentelè).

Kaip matome šioje lentelèje, greičiausiai sureaguoja kontrolinio pavyzdžio sacharozè. Ekstraktų pridejjimas ilgina reakcijos laiką. Mūsų atliktų tyrimų atveju ilgiausias sacharozès skilimo pusperiodis bandiniuose su melisų vandeniniu ekstraktu 14,5 val. ilgesnis nei kontrolinio bandinio. Bandinio su mètų ekstraktu skilimo pusperiodis ilgesnis už kontrolinio bandinio tą patị rodiklị beveik 11 val. Gali būti, kad reakcijos greiti titakoja terpès $\mathrm{pH}$ (17 lentelè), nes aktyviojo rūgštingumo skaitinès reikšmès nebuvo visiškai vienodos. Tačiau bandinio su mètų ekstraktu $\mathrm{pH}$ reikšmè daugiau nutolusi nuo kontrolinio bandinio $\mathrm{pH}$ reikšmès ị šarminę pusę nei su melisų ekstraktu. Reikètų manyti, kad medžiagos, išsiskiriančios ekstrahuojant vaistinius augalus vandeniu, veikia invertazę esančia meduje ir lètina katalitinio sacharozès skilimo reakciją.

Pagaminus produktus, panaudojant natūralią medaus invertazę, buvo ištirtos jų fizikinès-cheminès savybès, kurios pateiktos 18 lentelèje.

16 lentelè. Bandinių sacharozės skilimo reakcijos vidutinio greičio ir reakcijos pusperiodžiai

Table 16. Medium rate (turnover) and reaction half-lives of sucrose splitting (cleavage) in the samples

\begin{tabular}{|c|c|c|c|c|c|c|}
\hline & $\begin{array}{c}\text { Kontrolè } \\
\text { Control }\end{array}$ & 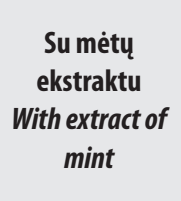 & $\begin{array}{l}\text { Su vaistinių ramunèlių } \\
\text { ekstraktu } \\
\text { With medicinal chamo- } \\
\text { mile extract }\end{array}$ & $\begin{array}{l}\text { Su smulkintų } \\
\text { liepu žiedy } \\
\text { ekstraktu } \\
\text { With crushed lime- } \\
\text { blossom extract }\end{array}$ & $\begin{array}{l}\text { Su nesmulkintų } \\
\text { liepǔ žiedų } \\
\text { ekstraktu } \\
\text { With whole lime } \\
\text { blossom extract }\end{array}$ & $\begin{array}{l}\text { Su melisos } \\
\text { ekstraktu } \\
\text { With melissa } \\
\text { extract }\end{array}$ \\
\hline $\begin{array}{l}\text { Vidutinis reakci- } \\
\text { jos greičio koefi- } \\
\text { cientas } \text { min }^{-1} \\
\text { The average of } \\
\text { reaction time } \\
\text { coefficient, } \text { min }^{-1}\end{array}$ & 0,000348 & 0,000262 & 0,000278 & 0,000299 & 0,000298 & 0,000242 \\
\hline $\begin{array}{l}\text { Reakcijos puspe- } \\
\text { riodis } h \\
\text { Reaction half- } \\
\text { lives, } h\end{array}$ & 33,2 & 44,1 & 41,5 & 38,6 & 38,7 & 47,7 \\
\hline
\end{tabular}

17 lentelè. Bandinių aktyvusis rūgštingumas pH

Table 17. Active acidity ( $\mathrm{pH}$ ) of the samples

\begin{tabular}{c|c|c|c|c|c}
\hline $\begin{array}{c}\text { Kontrolè } \\
\text { Control }\end{array}$ & $\begin{array}{c}\text { Su mètų ekstraktu } \\
\text { With extract of } \\
\text { mint }\end{array}$ & $\begin{array}{c}\text { Su vaistinių ramunèlių } \\
\text { ekstraktu } \\
\text { With medicinal chamomile } \\
\text { extract }\end{array}$ & $\begin{array}{c}\text { Su smulkintų liepų žiedų } \\
\text { ekstraktu } \\
\text { With crushed lime-blossom } \\
\text { extract }\end{array}$ & $\begin{array}{c}\text { Su nesmulkintų liepų žiedų } \\
\text { ekstraktu }\end{array}$ & $\begin{array}{c}\text { With whole lime blossom extract } \\
\text { With melissa extract }\end{array}$ \\
\hline 4,21 & 4,79 & 4,42 & 4,27 & 4,26 \\
\hline
\end{tabular}


18 lentelè. Produktų fizikinès-cheminès savybès

Table 18. Physical and chemical properties of the product

\begin{tabular}{|c|c|c|c|c|c|}
\hline $\begin{array}{l}\text { Produktas } \\
\text { Product }\end{array}$ & $\begin{array}{c}\text { Drègnis \% } \\
\text { Moisture, \% }\end{array}$ & $\begin{array}{l}\text { Pelenų kiekis \% } \\
\text { Ash content, \% }\end{array}$ & $\begin{array}{l}\text { Redukuojančiu sacharidų kiekis \% } \\
\text { Reducing sugars content, } \%\end{array}$ & $\begin{array}{l}\text { Sacharozės kiekis \% } \\
\text { Sucrose content, } \%\end{array}$ & pH \\
\hline $\begin{array}{l}\text { Kontrolinis } \\
\text { Control }\end{array}$ & 20,9 & 0,021 & 80,7 & 1,2 & 4,19 \\
\hline $\begin{array}{l}\text { Su mètų ekstraktu } \\
\text { With extract of mint }\end{array}$ & 22,3 & 0,143 & 79,3 & 2,1 & 4,76 \\
\hline $\begin{array}{l}\text { Su vaistinių ramunèlių ekstraktu } \\
\text { With extract of medicinal chamomile }\end{array}$ & 20,7 & 0,118 & 78,4 & 2,9 & 4,40 \\
\hline $\begin{array}{l}\text { Su smulkintų liepų žiedu ekstraktu } \\
\text { With extract of grated lime flowers }\end{array}$ & 23,0 & 0,190 & 79,8 & 2,5 & 4,25 \\
\hline $\begin{array}{l}\text { Su nesmulkintu liepu žiedu ekstraktu } \\
\text { With extract of whole lime flowers }\end{array}$ & 22,8 & 0,124 & 79,5 & 2,3 & 4,23 \\
\hline $\begin{array}{l}\text { Su melisos ekstraktu } \\
\text { With extract of melissa }\end{array}$ & 21,0 & 0,104 & 79,6 & 2,8 & 4,44 \\
\hline
\end{tabular}

Pagamintu produktu drègnis buvo kiek didesnis nei reikalaujama subrendusiam medui, tačiau mènesị laikant $35^{\circ} \mathrm{C}$ temperatūroje rūgimo procesų nepastebėta. Pelenų kiekis bandiniuose buvo didesnis nei kontroliniame, nes jas papildè ekstraktų sausosios medžiagos. Sacharozès kiekis visuose bandiniuose didesnis nei būna natūraliame žiedų meduje. Gali būti, kad sacharozès inversija tyrimų metu dar nebuvo pasibaigusi, nes ši reakcija žymiai sulètėja esant mažai substrato koncentracijai.

\section{IŠVADOS}

1. Atlikti bandymai parodè, kad vaistinių augalų vandeniniai ekstraktai lètina sacharozės fermentinès katalizės skilimo reakciją, panaudojant natūralią medaus invertazę.

2. Labiausiai sacharozès inversiją lètina melisų (Melissa officinalis L.) ir mètų (Mentha piperita L.) vandeniniai ekstraktai.

3. Technologiniu požiūriu natūralią meduje esančią invertazę galima naudoti sirupų, savo sudettimi artimų žiedų medui, gamybai.

\section{Literatūra}

1. Barnes J, Anderson L., Phillipson J. 2002. Herbal medicines a guide for healthcare professionals. 2nd ed. London: Pharmaceutical Press.

2. Ceksteryte V., Racys J. 2006. The quality of syrups used for bee feeding before winter and their suitability for bee wintering. Journal of Apicultural Science. Vol. 50. No. 1. P. 5-14.

3. Czaplicki J. 2003. Garść informacji o ziolomiodach. Pasieka. No. 3. P. 48-50.

4. Kranzberger B., Mair S. 2000. Pflanzenmonographien. München: Foitzick-Verlag.

5. Kranzberger B., Mair S. 2002. Handbuche der Heilpflanzen. Augsburg.

6. Malinauskas A. 2005. Cheminès kinetikos kurso konspektas. Vilnius. $48 \mathrm{p}$.

7. Pohorecka K. 2004. Effect of standardized plant herb extracts on general condition of the honeybee (Apis mellifera L.). Bull. Vet. Inst. Pulawy. No. 48. P. 415-419.

8. Дженке В. П. 1972. Катализ в химии и энзимологии. Москва. 314 с.

9. Йориш Н. П. 1976. Продукты пчеловодства и их использование. Москва: Россельхозиздат. 175 с.

Gauta 20111011

Priimta 20120206
10. Манапова Л. 3., Новиков В. Б. 2006. Методические разработки к практикуму по физической химии. Часть II. Химическая кинетика. Казань: КГУ. 35 с. 
Ervydas Juodišius, Aušra Šimonèlienė

\section{STUDIES ON THE PRODUCTION OF SYRUPS FOR \\ HUMAN NUTRITION ENRICHED WITH BIOLOGI- CALLY ACTIVE SUBSTANCES USING NATURAL HONEY INVERTASE}

Sum mary

The aim of the research was to explore possibilities for manufacturing products close to herbal honey (with regard to their composition) by means of sugar invertase contained in honey and aqueous extracts of dried medicinal plants, and to study the physical and chemical properties of the ready-made products.

The impact of the medicinal chamomile (Matricaria recutica L.), lime (Tilia cordata), melissa (Melissa officinalis L.) and peppermint (Mentha piperita L.) aqueous extracts on the reaction rate of the enzyme catalysis of sucrose was studied by means of natural invertase activity in flower honey. It was found that the medicinal plant extracts slow down the inversion process of sucrose. Of all the tested extracts the slowest enzymatic catalysis was found in melissa (Melissa officinalis L.) and in mint (Mentha piperita L.) aqueous extracts. The half-life of sucrose splitting (cleavage) in the samples of Melissa aqueous extract was longer by 14.5 hours than in the control sample, and that of the mint extract was 11 hours longer than in the control sample.

The physico-chemical characteristics of products made by means of natural flower honey invertase were close to similar parameters of natural honey. These products do not ferment at $35^{\circ} \mathrm{C}$, although the content of moisture is slightly higher than $20 \%$.

Key words: medicinal plant extract, honey, inversion, syrup 